\title{
Influence of Cutting Attachment on Noise Level Emitted by Brush Cutter during Tending of Young Forests
}

\author{
Bartłomiej Naskrent, Witold Grzywiński, Adrian Łukowski, Krzysztof Polowy
}

\begin{abstract}
A brush cutter is the most frequently used equipment for tending young forests. When cutting unwanted vegetation, the operator is exposed to various harmful factors, such as: a forced body position, noise, vibrations and exhaust emissions. In this study, the impact of cutting attachment type on the noise level during tending of young pine stands was examined. The attachments used during the tests included: a wire head and cutting blades with 2, 3 and 24 cutting teeth. The research was carried out on 2-3 year old Scots pine plantations covered with three types of vegetation: herbaceous, mixed and woody. It was proven that the the wire head was the device that generated the highest level of noise. In the case of cutting blades, the number of cutting teeth was the important factor. The greater the number of teeth in the cutting blades, the lower the noise level the device produced. There was no significant influence of vegetation type on noise emission level. Based on the results, in order to minimize operators' exposure to noise, the use of wire cutting attachment should be limited.
\end{abstract}

Keywords: brush cutter, cutting device, noise, forest plantation, silviculture

\section{Introduction}

Spring and summer are periods of intensive silvicultural works like weeding in young stands and early cleaning. According to Jaworski (2013), the cultivation/tending of younger stands is mainly related to weed control and soil care by loosening the soil with the use of hand tools (hoes) or mechanical tools (disc harrows, weeders). In older forests, early cleaning is performed by removing or inhibiting the growth of redundant admixture species, removing diseased, deformed and older trees or trees that are too large, and thinning out overly dense parts of the plantation. In 2017 , soil cultivation and weed cutting was carried out on 178.1 thousand hectares on the area managed by the State Forests National Forest Holding in Poland (Statistical... 2018).

In the past, these tasks were performed using simple hand tools: machetes, axes and scythes. It was a very hard and inefficient job requiring a significant energy expenditure from the workers (Grzywiński 2009; International Labour Office 1998). Cutting weeds on plantations with scythe caused energy expenditure of up to $10.1 \mathrm{MJ} \times 8 \mathrm{~h}^{-1}$ (Grzywiński 2009). Some features of plantation tending inhibit mechanization: close spacing between trees and rows (approx. $1.5 \mathrm{~m}$ ), large number of trees (4-10 thousand per ha) and numerous terrain obstacles (e.g. stumps, stones). Workers carrying the tasks are usually paid per piece rate. Their remuneration depends on the successfully managed area - irrespective of difficulty. Toupin et al. (2007) claim that this may directly lead to hazardous behaviours on the part of the workers who put their health and safety at risk. As a result of the abovementioned factors, new technologies and techniques of tending young stands are needed that would benefit the workers' safety and efficiency, and limit the energy expenditure.

Brush cutters (mechanical scythes) are used for cutting herbaceous plants in forest plantations (Dubeau et al. 2012; International Labour Office 1998; Więsik and Aniszewska 2011). These are portable machines hooked to a harness and controlled manually, equipped with a cutting attachment on a rod, about $1 \mathrm{~m}$ long (Więsik et al. 2005, Wójcik 2008, 2015). Professional brush cutters weigh around 8-9 kg with accessories 
and their power is about $2 \mathrm{~kW}$ (Uusitalo 2010). Grzywiński (2009) investigated the energy expenditure of tending forest plantations with a brush cutter. This research showed that total energy expenditure for an 8-hour shift was $3.9 \mathrm{MJ} \times 8 \mathrm{~h}^{-1}$, which classifies mechanical weed cutting as a moderately heavy work.

Mechanical brush cutters are equipped with an internal combustion engine, which affects the operators' health and safety by producing noise, vibration and exhaust emissions. Noise severely affects the health among brush cutters (Dziurdź 2011, Ising and Kruppa 2004, Muzet 2002, Nelson et al. 2005, Pettersson 2013). The most common symptoms are: hearing loss, stress, irritation, memory loss and sleep disturbance (Nelson et al. 2005, Ouis 1999, Shah et al. 2018, Stansfeld et al. 2000, Tengku et al. 2013). Long-term exposure to vibrations may also have negative health effects in the form of vascular, neurological and musculoskeletal disorders (Dziurdź 2011, Ko et al. 2011, Pettersson 2013, Truța et al. 2013). Various aspects of working with a brush cutter have been researched by many authors; however, the issue of noise level emitted by different cutting attachments while tending forest plantations has not been assessed yet.

The aim of the study is to show the differences in the noise level emitted by brush cutters with the use of various types of cutting attachments in tending forest plantations affected by weeds of herbaceous, woody and mixed plants. According to our hypothesis, cutting units aggregated to the brush cutter have a significant impact on the level of emitted noise. The results may prove helpful when selecting a proper cutting attachment for brush cutters to reduce arduousness at work.

\section{Materials and Methods}

Measurements of noise exposure were carried out in summer 2018 during tending of forest plantations in one of the forest districts of southwestern Poland. The research was carried out on three forest plantations aged $2-3$ years. The cutting devices used in the study included: a wire head Speed Feed with an Oregon Flexiblade $2.4 \mathrm{~mm}$ wire and cutting blades with 2, 3 and 24 cutting teeth (multi-tooth blade) (Fig. 1). All these devices were mounted on the same brush cutter - a semi-professional Shindaiwa C 3410 with engine capacity of $34.0 \mathrm{~cm}^{3}$ and $1.11 \mathrm{~kW}$ power. Measurements were conducted during sunny and windless weather, and the brush cutter was operated by the same person throughout the entire study.

Depending on the type of mown plant cover, the study was executed in three variants: herbaceous veg-

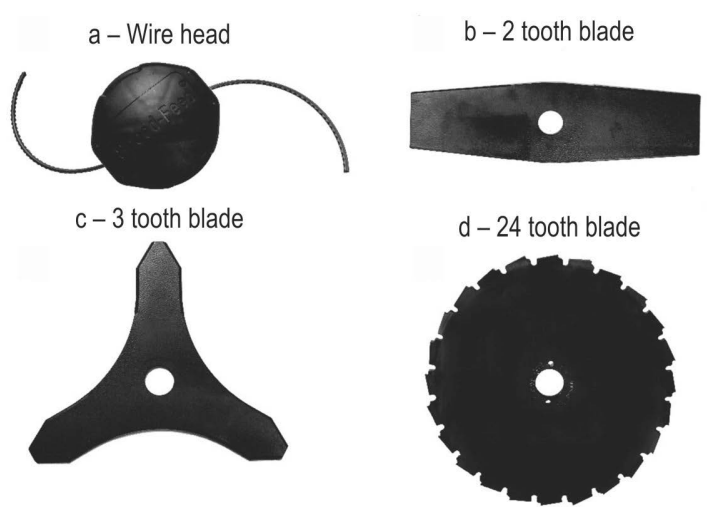

Fig. 1 Cutting devices used in the study

etation (grasses, sedges, etc.), mixed vegetation (grasses, sedges, brushes, blackberries, small trees) and woody vegetation (trees with a diameter exceeding $1 \mathrm{~cm}$ ). In the first two variants, all cutting devices were tested in 15 repetitions, 5 minutes each $(n=2$ vegetation variants $\times 4$ cutting units $\times 15$ samples). In the case of woody vegetation, only the 3 tooth and 24 tooth blades were examined, due to the risk of damaging the brush cutter when using a 2 tooth blade, and to avoid an excessive use of cutting wire $(n=1$ vegetation variant $\times 2$ cutting devices $\times 15$ samples). The operator worked at the same regular pace and using the same technique in all variants. In order to calculate the Aweighted noise exposure in an $8 \mathrm{~h}$ working shift, a constant effective working time of $4.96 \mathrm{~h}$ per day was assumed - following the results of Sowa et al. (2002).

Measurements were done using a SVANTEK SV 102 dosimeter. The following parameters were registered:

$$
\begin{aligned}
\Rightarrow & L_{\mathrm{Amax}}(\mathrm{dB})-\mathrm{A} \text {-weighted maximum sound pres- } \\
& \text { sure level } \\
\Rightarrow & L_{\mathrm{Cpeak}}(\mathrm{dB})-\mathrm{C} \text {-weighted peak sound pressure } \\
& \text { level } \\
\Rightarrow & L_{\mathrm{Aeq}}(\mathrm{dB})-\mathrm{A} \text {-weighted equivalent continuous } \\
& \text { sound pressure level } \\
\Rightarrow & L_{\mathrm{Ex}, 8 \mathrm{~h}}(\mathrm{~dB})-\mathrm{A} \text {-weighted noise exposure level } \\
& \text { normalized to a nominal } 8 \mathrm{~h} \text { working day. }
\end{aligned}
$$

Noise measurements were conducted according to norm EN ISO 22868. In order to keep a fixed distance between the sensor and cutting device during measurements, the microphone was mounted at the top of the operator's helmet - about $10 \mathrm{~cm}$ from his ear and about $90 \mathrm{~cm}$ form brush cutter suspension hook. The distance from the engine was about $60 \mathrm{~cm}$.

The A-weighted noise exposure level normalized to an $8 \mathrm{~h}$ working day was calculated according to the formula (EN ISO 9612:2009): 


$$
L_{\mathrm{EX}, 8 \mathrm{~h}}=L_{\text {AeqTe }}+10 \log \left(\frac{\mathrm{Te}}{\text { To }}\right)
$$

Where:

$L_{\text {AeqTe }}$ A-weighted equivalent continuous sound pressure level for $T_{\mathrm{e}}$

$T_{\mathrm{e}} \quad$ effective duration of the working day, in hours $T_{0} \quad$ reference duration, $T_{0}=8 \mathrm{~h}$

Average sound pressure levels were calculated according to the formula (Figlus et al. 2013):

Where:

$$
L_{\mathrm{x}}=10 \times \log \left(\frac{1}{n} \sum_{\mathrm{k}=1}^{\mathrm{n}} 10^{0.1 \times L_{\mathrm{k}}}\right)
$$

$n \quad$ number of measurements

$L_{\mathrm{k}} \quad$ sound pressure level during k measurement, $\mathrm{dB}$.

Statistical analyses were performed using the Statistica v. 13 software package (StatSoft Inc., Tulsa, OK, USA). As the data were not normally distributed, a nonparametric Kruskall-Wallis test was used. Nonparametric comparisons for each pair were made using Wilcoxon Rank Sums Test (nonparametric version of Each Pair, Student's t method; $\alpha=0.05$ ). In Tables 1 and 2, average sound pressure levels calculated according to equation 2 and exposures calculated according to equation 1 are presented for various attachments and plant cover types. Different letters indicate that the means are significantly different $(p<0.05)$.

\section{Results}

The analysis of recorded data showed that the acoustic energy $L_{\mathrm{Ex}, 8 \mathrm{~h}}$ received by the operator working on the brush cutter equipped with wire head was significantly greater comparing to 24 tooth blade, regardless of vegetation type. Other cutting attachments emitted much lower noise levels. The 2 tooth blade generated significantly less acoustic energy than a wire head when cutting herbaceous and mixed vegetation.

\begin{tabular}{|c|c|c|c|c|c|c|c|c|c|}
\hline \multirow{3}{*}{ Cutting device } & \multicolumn{9}{|c|}{ Herbaceous vegetation } \\
\hline & \multirow{2}{*}{$n$} & \multicolumn{8}{|c|}{ Mean } \\
\hline & & \multicolumn{2}{|c|}{$L_{\text {Amax }} d B$} & \multicolumn{2}{|c|}{$L_{\text {Cpeak }} \mathrm{dB}$} & \multicolumn{2}{|c|}{$L_{\text {Aeq, }} \mathrm{dB}$} & \multicolumn{2}{|c|}{$L_{E x x^{\prime g} h^{\prime}} \mathrm{dB}$} \\
\hline Wire head & 15 & \multicolumn{2}{|c|}{$97.6060 \mathrm{a}$} & \multicolumn{2}{|c|}{$122.1492 \mathrm{a}$} & \multicolumn{2}{|c|}{94.6602 a } & \multicolumn{2}{|c|}{$92.5842 \mathrm{a}$} \\
\hline 2 tooth blade & 15 & \multicolumn{2}{|c|}{$95.1992 b$} & \multicolumn{2}{|c|}{$118.5511 \mathrm{~b}$} & \multicolumn{2}{|c|}{$89.3025 b$} & \multicolumn{2}{|c|}{$87.2264 b$} \\
\hline 3 tooth blade & 15 & \multicolumn{2}{|c|}{$95.7070 \mathrm{~b}$} & \multicolumn{2}{|c|}{$117.8251 \mathrm{~b}$} & \multicolumn{2}{|c|}{$89.1312 b$} & \multicolumn{2}{|c|}{$87.0551 \mathrm{~b}$} \\
\hline 24 tooth blade & 14 & \multicolumn{2}{|c|}{$93.9280 \mathrm{~b}$} & \multicolumn{2}{|c|}{$114.1140 \mathrm{c}$} & \multicolumn{2}{|c|}{$88.6901 \mathrm{~b}$} & \multicolumn{2}{|c|}{86.6141 b } \\
\hline \multirow{2}{*}{\multicolumn{2}{|c|}{$\begin{array}{l}\text { Results of nonparametric } \\
\text { Kruskall-Wallis tests }\end{array}$}} & $\chi^{2}$ & $p$ & $\chi^{2}$ & $p$ & $\chi^{2}$ & $p$ & $\chi^{2}$ & $p$ \\
\hline & & 16.39 & 0.0009 & 39.65 & $<0.0001$ & 39.02 & $<0.0001$ & 39.02 & $<0.0001$ \\
\hline \multirow{3}{*}{ Cutting device } & \multicolumn{9}{|c|}{ Mixed vegetation } \\
\hline & \multirow{2}{*}{$n$} & \multicolumn{8}{|c|}{ Mean } \\
\hline & & \multicolumn{2}{|c|}{$L_{\text {Amax }} \mathrm{dB}$} & \multicolumn{2}{|c|}{$L_{\text {Cpeak },} \mathrm{dB}$} & \multicolumn{2}{|c|}{$L_{\text {Aeq }}, \mathrm{dB}$} & & \\
\hline Wire head & 15 & & & & $555 \mathrm{a}$ & & $99 \mathrm{a}$ & & $38 \mathrm{a}$ \\
\hline 2 tooth blade & 15 & & & & $61 \mathrm{~b}$ & & $96 \mathrm{~b}$ & & $35 \mathrm{~b}$ \\
\hline 3 tooth blade & 14 & & & & $345 c$ & & $66 \mathrm{~b}$ & & $2 \mathrm{~b}$ \\
\hline 24 tooth blade & 15 & & & & $32 \mathrm{c}$ & & $89 \mathrm{c}$ & & $28 \mathrm{c}$ \\
\hline Results of nonpara & & $\chi^{2}$ & $p$ & $\chi^{2}$ & $p$ & $\chi^{2}$ & $p$ & $\chi^{2}$ & $p$ \\
\hline Kruskall-Wallis test & & 28.86 & $<0.0001$ & 40.19 & $<0.0001$ & 50.23 & $<0.0001$ & 50.23 & $<0.0001$ \\
\hline & & & & & Woody v & ation & & & \\
\hline Cutting device & & & & & & & & & \\
\hline & $n$ & & & & & & & & \\
\hline 3 tooth blade & 15 & & & & $37 \mathrm{a}$ & & $80 \mathrm{a}$ & & $9 a$ \\
\hline 24 tooth blade & 15 & & & & $57 \mathrm{~b}$ & & $93 \mathrm{~b}$ & & $2 \mathrm{~b}$ \\
\hline Results of nonpara & & $\chi^{2}$ & $p$ & $\chi^{2}$ & $p$ & $\chi^{2}$ & $p$ & $\chi^{2}$ & $p$ \\
\hline Wilcoxon tests & & 8.93 & 0.0028 & 21.22 & $<0.0001$ & 19.18 & $<0.0001$ & 19.18 & $<0.0001$ \\
\hline
\end{tabular}

Table 1 Mean values of measured noise parameters; different letters indicate that means are significantly different at $p<0.05$ 
Table 2 Mean values of measured noise parameters; different letters indicate that means are significantly different at $p<0.05$

\begin{tabular}{|c|c|c|c|c|c|c|c|c|c|}
\hline \multirow{3}{*}{ Vegetation variant } & \multirow{3}{*}{$n$} & \multicolumn{8}{|c|}{ Wire head } \\
\hline & & \multicolumn{8}{|c|}{ Mean } \\
\hline & & \multicolumn{2}{|c|}{$L_{\text {Amax, }}, \mathrm{dB}$} & \multicolumn{2}{|c|}{$L_{\text {Cpeak, }} \mathrm{dB}$} & \multicolumn{2}{|c|}{$L_{\text {Aeq, }} \mathrm{dB}$} & \multicolumn{2}{|c|}{$L_{\mathrm{EX}, 8 h}, \mathrm{~dB}$} \\
\hline Herbaceous vegetation & 15 & \multicolumn{2}{|c|}{97.6060} & \multicolumn{2}{|c|}{122.1492} & \multicolumn{2}{|c|}{94.6602} & \multicolumn{2}{|c|}{92.5842} \\
\hline Mixed vegetation & 15 & \multicolumn{2}{|c|}{97.1779} & \multicolumn{2}{|c|}{122.7555} & \multicolumn{2}{|c|}{93.6899} & \multicolumn{2}{|c|}{91.6138} \\
\hline \multicolumn{2}{|l|}{$\begin{array}{l}\text { Results of nonparametric } \\
\text { Wilcoxon tests }\end{array}$} & $\chi^{2}$ & $p$ & $\chi^{2}$ & $p$ & $\chi^{2}$ & $p$ & $\chi^{2}$ & $p$ \\
\hline & & 0.62 & 0.4302 & 0.95 & 0.3295 & 1.16 & 0.2806 & 1.16 & 0.2806 \\
\hline \multirow{3}{*}{ Vegetation variant } & & \multicolumn{8}{|c|}{2 tooth blade } \\
\hline & \multirow{2}{*}{$n$} & \multicolumn{8}{|c|}{ Mean } \\
\hline & & \multicolumn{2}{|c|}{$L_{\text {Amax }}, \mathrm{dB}$} & \multicolumn{2}{|c|}{$L_{\text {Cpeak, }} \mathrm{dB}$} & \multicolumn{2}{|c|}{$L_{\text {Aeq, }} \mathrm{dB}$} & \multicolumn{2}{|c|}{$L_{E x, 8 h}, d B$} \\
\hline Herbaceous vegetation & 15 & \multicolumn{2}{|c|}{$95.1992 \mathrm{~b}$} & \multicolumn{2}{|c|}{$118.5511 \mathrm{~b}$} & \multicolumn{2}{|c|}{89.3025 b } & \multicolumn{2}{|c|}{$87.2264 b$} \\
\hline Mixed vegetation & 15 & & $19 a$ & & 61 a & & 96 a & & \\
\hline Results of nonparametric & & $\chi^{2}$ & $p$ & $\chi^{2}$ & $p$ & $\chi^{2}$ & $p$ & $\chi^{2}$ & $p$ \\
\hline Wilcoxon tests & & 16.03 & $<0.0001$ & 12.90 & 0.0003 & 21.71 & $<0.0001$ & 21.71 & $<0.0001$ \\
\hline & & & & & 3 to & & & & \\
\hline Vegetation variant & & & & & & & & & \\
\hline & 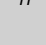 & & & & & & & & \\
\hline Herbaceous vegetation & 15 & & & & $51 \mathrm{~b}$ & & $12 \mathrm{c}$ & & \\
\hline Mixed vegetation & 14 & & & & $45 c$ & & $36 \mathrm{~b}$ & & $2 \mathrm{~b}$ \\
\hline Woody vegetation & 15 & & & & 37 a & & $30 \mathrm{a}$ & & \\
\hline Results of nonparametric & & $\chi^{2}$ & $p$ & $\chi^{2}$ & $p$ & $\chi^{2}$ & $p$ & $\chi^{2}$ & $p$ \\
\hline Kruskall-Wallis tests & & 18.90 & 0.0028 & 23.18 & $<0.0001$ & 33.25 & $<0.0001$ & 33.25 & $<0.0001$ \\
\hline & & & & & 24 tc & & & & \\
\hline Vegetation variant & $n$ & & & & & & & & \\
\hline & " & & & & & & & & \\
\hline Herbaceous vegetation & 14 & & & & & & $01 \mathrm{~b}$ & & \\
\hline Mixed vegetation & 15 & & & & & & $39 \mathrm{c}$ & & \\
\hline Woody vegetation & 15 & & & & & & $33 \mathrm{~b}$ & & \\
\hline Results of nonparametric & & $\chi^{2}$ & $p$ & $\chi^{2}$ & $p$ & $\chi^{2}$ & $p$ & $\chi^{2}$ & $p$ \\
\hline Kruskall-Wallis tests & & 10.49 & 0.0053 & 5.03 & 0.0810 & 31.55 & $<0.0001$ & 31.55 & $<0.0001$ \\
\hline
\end{tabular}

The 3 tooth blade was slightly quieter than the 2 tooth blade in all vegetation variants. The 24 tooth blade emitted the lowest amount of acoustic energy in all examined vegetation types (Table 1 ).

Mean acoustic pressure level for measurement pe$\operatorname{riod}\left(L_{\text {Aeq }}\right)$ was also the highest in the case of the wire head. The difference between the wire head and 24 tooth blade was about $6 \mathrm{~dB}$ when cutting in herbaceous and mixed vegetation, whereas differences between blades were about $1-2 \mathrm{~dB}$. The 24 tooth blade emitted $2 \mathrm{~dB}$ less acoustic pressure $\left(L_{\text {Aeq }}\right)$ while cutting woody vegetation (Table 1 ).
The statistical analysis of the amount of acoustic energy $\left(L_{\mathrm{EX}, 8 \mathrm{~h}}\right)$ emitted by the brush cutter and mean acoustic pressure level $\left(L_{\text {Aeq }}\right)$ showed significant differences between the wire head and the rest of the cutting devices during cutting of herbaceous plants (Table 1). In the mixed vegetation variant, significant differences were found between the wire head and cutting blades, as well as between the 24-tooth blade and the rest of the blades. The statistical analysis also confirmed significant differences between the 3-tooth blade and the 24 tooth blade during cutting of woody plants (Table 1). 
The type of cut vegetation also proved to have influence on noise level. In the case of all blade attachments, there was a significant difference in noise level depending on the type of vegetation. In the case of wire head, however, the type of cut plants did not have a significant impact (Table 2).

\section{Discussion}

It is well known that noise has a significant impact on human health, and the main risk connected with exposure to noise at work involves a temporary or permanent hearing damage. All workers who are or are likely to be exposed to risks related to noise as a result of their work should be protected against its negative effects. Operators of motor-manual machines, like brush cutters while tending young forest plantations, are particularly exposed to high noise levels. The study showed that both cutting attachement and the type of cut vegetation influenced the noise emission level. The obtained results indicate that hearing protection must be used as the exposures in all variants exceeded $85 \mathrm{~dB}$, according to the Directive 2003/10/EC.

The wire head was the device that emitted the highest noise level in all vegetation variants. This may be caused by various reasons. For example, the length and thickness of the wire influences the cutting resistance, which forces the operator to increase engine revolutions. According to Sorică (2018), the engine revolutions per minute have a significant influence on the sound pressure and sound energy levels, which increase as the engine rpm increases. When cutting the plants, the cutting wire encounters many different types of obstacles, such as forest dead wood, small trees, hard plant stems, which cause its radial and axial deformations. These deformations cause a significant increase in noise levels (Shao et al. 2010). According to Mallick (2010), the optimal length of the cutting wire during cutting should not exceed $10 \mathrm{~cm}$. As far as cutting blades are concerned, it is possible to use the inertia force of the cutting disc, which means that the motor does not have to be maintained at a high speed.

Moreover, our study showed that the number of cutting teeth had a significant impact on the emission of acoustic energy. As the number of teeth in the cutting device increased, the noise emission level decreased. A statistical analysis confirmed that the least noise was generated by the 24 tooth blade. Similar conclusions were also achieved by other authors (Kvietková et al. 2015).

There are many other factors that significantly influence the noise level when using a brush cutter. One of these elements influencing the operator's exposure to noise is a cumulative effect of several operators working in close proximity (Mallick 2009). While working in teams, operators should keep a distance of minimum $15 \mathrm{~m}$ between each other to avoid cumulative exposure to noise (Haron et al. 2015). On the other hand, the engine power and capacity, as well as its technical condition, directly impact the noise level to which the operator is exposed (Figlus et al. 2013).

The present study is one of the few dedicated to the issue of noise level emitted by a brush cutter when cutting unwanted plants in forest plantations. This study focuses on the influence of the cutting attachment type and type of cut vegetation on the noise level, which significantly affects the operator's exposure to it. The authors realize that, apart from these two, other factors (technical, organizational) may have an impact on the noise level produced by brush cutter work. It is therefore necessary to carry out further research on this subject, with a view to introducing solutions to minimize the harmful effects of noise at work. It is also crucial to increase the awareness and knowledge of employees about the harmful effects of noise, as well as to promote the use of personal protective equipment allowing to reduce its negative effects.

\section{Conclusions}

$\Rightarrow$ Both cutting attachment and cut vegetation significantly influence the noise level

$\Rightarrow$ The wire head is the cutting attachment that causes the highest noise emissions

$\Rightarrow$ The number of cutting teeth in the cutting blade influences the noise level significantly - with the increase in the number of teeth, the noise level decreases.

\section{Acknowledgments}

Publication was co-financed within the framework of the Polish Ministry of Science and Higher Education program: »Regional Initiative Excellence « in the period 2019-2022 (No. 005/RID/2018/19).

\section{References}

Directive 2003/10/EC of the European Parliament and of the Council of 6 February 2003 on the minimum health and safety requirements regarding the exposure of workers to the risks arising from physical agents (noise) (Seventeenth individual Directive within the meaning of Article 16(1) of Directive 89/391/EEC). https://eur-lex.europa.eu/legal-content/EN/TXT/?uri=CELEX:32003L0010 
Dubeau, D., Lebel, L.G., Imbeau, D., Auger, I., 2012: Impacts of vegetation abundance and terrain obstacles on brushcutter performance during regeneration release. Northern Journal of Applied Forestry 29(4): 173-181. https://doi. org/10.5849/njaf.11-025

Dziurdź, J., 2011: Zagrożenia człowieka w środowisku pracy. Drgania i hałas. Politechnika Warszawska: Warsaw, Poland.

Figlus, T., Wilk, A., Franke, P., 2013: The estimation of changes in the noise level generated by devices equipped with twostroke internal combustion engines with small displacement volume. FME Transactions 41(3): 216-221.

Grzywiński, W., 2009: Energy expenditure in some silvicultural works. Electronic Journal of Polish Agricultural Universities 12(4): 20 p.

Haron, Z., Darus, N., Han, L.M., Jahya, Z., Hamid, M.F.A., Yahya, K., Lee, Y.L., Shek, P.N., 2015: A preliminary study of occupational noise exposure among leaf blower and grass cutter workers in public university. Jurnal Teknologi 77(16): 153-159. https://doi.org/10.11113/jt.v77.6412

International Labour Office (Ed.), 1998: Safety and health in forestry work. International Labour Office: Geneva, Switzerland.

Ising, H., Kruppa, B., 2004: Health effects caused by noise: Evidence in the literature from the past 25 years. Noise Health 6(22): 5-13.

Jaworski, A., 2013: Hodowla Lasu. Tom II Pielęgnowanie lasu. Powszechne Wydawnictwo Rolnicze i Leśne: Warsaw, Poland.

Ko, Y.H., Ooi, L.E., Zaidi, M.R., 2011: The design and development of suspended handles for reducing hand-arm vibration in petrol driven grass trimmer. International Journal of Industrial Ergonomics 41(5): 459-70. https://doi.org/10.1016/j. ergon.2011.04.004

Kvietková, M., Gaff, M., Gašparík, M., Kminiak, R., Kriš, A., 2015: Effect of number of saw blade teeth on noise level and wear of blade edges during cutting of wood. BioResources 10(1): 1657-1666.

Mallick, Z., 2010: Optimization of the operating parameters of a grass trimming machine. Applied Ergonomics 41(2): 260-265. https://doi.org/10.1016/j.apergo.2009.07.010

Mallick, Z., Badruddin, I.A., Khaleed Hussain, M.T., Salman Ahmed, N.J., Kanesan, J., 2009: Noise characteristics of grasstrimming machine engines and their effect on operators. Noise Health 11(43): 98-102.

Muzet, A., 2002: The need for a specific noise measurement for population exposed to aircraft noise during night-time. Noise Health 4(15): 61-64.

Nelson, D.I., Nelson, R.Y., Concha-Barrientos, M., Fingerhut, M., 2005: The global burden of occupational noise-induced hearing loss. American Journal of Industrial Medicine 48(6): 446-458. https://doi.org/10.1002/ajim.20223

Ouis, D., 1999: Exposure to nocturnal road traffic noise: Sleep disturbance and its after effects. Noise Health 1(4): 11-36.
Pettersson, H., 2013: Risk of hearing loss from combined exposure to hand-arm vibrations and noise. Umeå University Umeå.

Shah, R.R., Suen, J.J., Cellum, I.P., Spitzer, J.B., Lalwani, A.K., 2018: The effect of brief subway station noise exposure on commuter hearing. Laryngoscope Investigative Otolaryngology 3(6): 486-491. https://doi.org/10.1002/lio2.216

Shao, X., Shan, C., Pan, J., 2010: An experimental research of the cutter deformation for minitype grass trimmer. Proceedings of the Second China Energy Scientist Forum, Xuzgou, Jiangsu, China, 18-19 October. Jiongtian, L., Weidou, N., Eds.; Scientific Research Publishing Inc., vol. 1-3 (1090-1092).

Sorică, E., Vlăduț, V., Cârdei, P., Sorică, C., Brăcăcescu, C., 2018: Comparative analysis of the noise and vibration transmitted to the operator by a brush cutter. In: Acoustics and Vibration of Mechanical Structures-AVMS-2017, Proceedings of the $14^{\text {th }}$ AVMS Conference, Timisoara, Romania, May 25-26, 2017. Herisanu, N., Vasilae, M., Eds.; vol. 198 (165172), Springer: Cham, Switzerland.

Sowa, J.M., Szewczyk, G., Kulak, D., Pasiowiec, W., 2002: Analysis of shift time structure during tree culture cultivation with brush cutters. Zeszyty Problemowe Postepów Nauk Rolniczych 486(1): 129-137.

Stansfeld, S., Haines, M., Brown, B., 2000: Noise and health in the urban environment. Reviews on Environmental Health 15(1-2): 43-82. https://doi.org/10.1515/REVEH.2000.15.1-2.43

Statistical Yearbook of Forestry 2018: 2018. Statistics Poland, Warsaw. Available at https://stat.gov.pl/en/topics/statisticalyearbooks/statistical-yearbooks/statistical-yearbook-of-forestry-2018,12,1.html

Tengku, H.T.I., Amirah, A.M.J., Ramdzani, A., Madinah, A., 2013: A preliminary study of noise exposure among grass cutting workers in malaysia. Procedia - Social and Behavioral Sciences 91: 661-672. https://doi.org/10.1016/j.sbspro.2013.08.467

Toupin, D., LeBel, L., Dubeau, D., Imbeau, D., Bouthillier, L., 2007: Measuring the productivity and physical workload of brushcutters within the context of a production-based pay system. Forest Policy and Economics 9(8): 1046-1055. https:// doi.org/10.1016/j.forpol.2006.10.001

Truța, A., Cristea, F.A., Arghir, M., 2013: The influence of brush cutter's vibrations on human body. Advanced Engineering Forum 8-9: 445-452. https://doi.org/10.4028/www. scientific.net/AEF.8-9.445

Uusitalo, J., 2010: Introduction to forest operations and technology. JVP Forest Systems Oy.

Więsik, J., Aniszewska, M., 2011: Urządzenia techniczne w produkcji leśnej. Urządzenia do hodowli i ochrony lasu. Tom 1. Wydawnictwo SGGW: Warsaw, Poland.

Więsik, J., Wójcik, K., Kozłowski, R., Neugebauer, Z., 2005, Pilarki przenośne - budowa i eksploatacja. Fundacja Rozwój SGGW: Warsaw, Poland. 
Wójcik, K., 2008: Analiza parametrów technicznych i eksploatacyjnych profesjonalnych wysięgnikowych pilarek spalinowych oferowanych na rynku europejskim. Technika Rolnicza Ogrodnicza i Leśna 3: 3-6.

Wójcik, K., 2015: Wpływ elementu tnącego na drgania emitowane przez kosy spalinowe do zarośli i trawy. Leśne Prace Badawcze 76(4): 331-340. https://doi.org/10.1515/frp-20150032
EN ISO 22868:2011, 2011: Forestry and gardening machinery - Noise test code for portable hand-held machines with internal combustion engine - Engineering method (Grade 2 accuracy).

ISO 9612:2009, 2009: Acoustics - Determination of occupational noise exposure - Engineering method.

https://shindaiwa.pl/kosy-spalinowe/c3410x.html (access: 17.12.2018) (in Polish)

(C) 2019 by the authors. Submitted for possible open access publication under the terms and conditions of the Creative Commons Attribution (CC BY) license (http://creativecommons.org/licenses/by/4.0/).

Received: April 19, 2019

Accepted: September 26, 2019
Authors' addresses:

Bartłomiej Naskrent, MSc e-mail: bartlomiej.naskrent@up.poznan.pl Assoc. prof. Witold Grzywiński, PhD e-mail: witold.grzywinski@up.poznan.pl Poznan University of Life Sciences Department of Forest Utilisation Wojska Polskiego 71A 60-625 Poznań POLAND

Adrian Łukowski, PhD e-mail: adrian.lukowski@up.poznan.pl Poznan University of Life Sciences Department of Silviculture Wojska Polskiego 71 D 60-625 Poznań

POLAND

Krzysztof Polowy, PhD * e-mail: krzypol@up.poznan.pl Poznan University of Life Sciences Department of Forest Technology Wojska Polskiego 71C 60-625 Poznań POLAND

* Corresponding author 